\title{
T4 RNA ligase catalyzes the synthesis of dinucleoside polyphosphates
}

\author{
Eva Ana Atencia, Olga Madrid, María A. Günther Sillero and Antonio Sillero \\ Instituto de Investigaciones Biomédicas Alberto Sols, UAM/CSIC, Departamento de Bioquímica, Facultad de Medicina, Madrid, Spain
}

\begin{abstract}
T4 RNA ligase has been shown to synthesize nucleoside and dinucleoside $5^{\prime}$-polyphosphates by displacement of the AMP from the E-AMP complex with polyphosphates and nucleoside diphosphates and triphosphates. Displacement of the AMP by tripolyphosphate $\left(\mathrm{P}_{3}\right)$ was concentration dependent, as measured by SDS/PAGE. When the enzyme was incubated in the presence of $0.02 \mathrm{~mm}\left[\alpha{ }^{32} \mathrm{P}\right]$ ATP, synthesis of labeled $\mathrm{Ap}_{4} \mathrm{~A}$ was observed: ATP was acting as both donor $\left(K_{\mathrm{m}}, \mu \mathrm{M}\right)$ and acceptor $\left(K_{\mathrm{m}}, \mathrm{mM}\right)$ of AMP from the enzyme. Whereas, as previously known, ATP or dATP (but not other nucleotides) were able to form the E-AMP complex, the specificity of a compound to be acceptor of AMP from the E-AMP complex was very broad, and with $K_{\mathrm{m}}$ values between 1 and $2 \mathrm{~mm}$. In the presence of a low concentration $(0.02 \mathrm{mM})$ of $\left[\alpha{ }^{32} \mathrm{P}\right]$ ATP (enough to form the E-AMP complex, but only marginally enough to form $\mathrm{Ap}_{4} \mathrm{~A}$ ) and $4 \mathrm{~mm}$ of the indicated nucleotides or $\mathrm{P}_{3}$, the relative rate of synthesis of the following radioactive (di)nucleotides was observed: $\mathrm{Ap}_{4} \mathrm{X}$ (from XTP, 100); $\mathrm{Ap}_{4} \mathrm{dG}$ (from dGTP, 74); $\mathrm{Ap}_{4} \mathrm{G}$ (from GTP, 49); $\mathrm{Ap}_{4} \mathrm{dC}$ (from dCTP, 23); $\mathrm{Ap}_{4} \mathrm{C}$ (from CTP, 9); $\mathrm{Ap}_{3} \mathrm{~A}$ (from ADP, 5); $\mathrm{Ap}_{4} \mathrm{ddA}$, (from ddATP, 1); $\mathrm{p}_{4} \mathrm{~A}$ (from $\mathrm{P}_{3}, 200$ ). The enzyme also synthesized efficiently $\mathrm{Ap}_{3} \mathrm{~A}$ in the presence of $1 \mathrm{~mm}$ ATP and $2 \mathrm{~mm}$ ADP. The following T4 RNA ligase donors were inhibitors of the synthesis of $\mathrm{Ap}_{4} \mathrm{G}: \mathrm{pCp}>\mathrm{pAp}>\mathrm{pA2}$.
\end{abstract}

Keywords: RNA ligase; dinucleoside polyphosphates; $\mathrm{Ap}_{3} \mathrm{~A}$; RNA joining; firefly luciferase.

Dinucleoside polyphosphates $\left(\mathrm{Np}_{\mathrm{n}} \mathrm{N}\right.$, a family of $5^{\prime}, 5^{\prime}$-linked dinucleotides) are molecules involved in metabolic regulation and cell signaling [1-3]. These compounds, mainly diadenosine polyphosphates $\left(\mathrm{Ap}_{\mathrm{n}} \mathrm{A}\right)$, have been implicated in a variety of intra and extracellular roles such as: regulation of purine nucleotide metabolism, alarmones acting in the heat shock and oxidative stresses, transition-state analogues of some kinases, control of cell division, neurotransmitters, vasoregulators,

Correspondence to A. Sillero, Departamento de Bioquímica, Facultad de Medicina,, Universidad Autónoma de Madrid, Arzobispo Morcillo, 4, 28029 Madrid, Spain. Fax: + 34913975353 ,

Tel.: + 3491 3975413, E-mail: antonio.sillero@uam.es

Abbreviations: $\mathrm{Ap}_{3} \mathrm{~A}$, adenosine $\left(5^{\prime}\right)$ triphospho( $\left.5^{\prime}\right)$ adenosine or diadenosine triphosphate; $\mathrm{Ap}_{3} \mathrm{X}$, adenosine $\left(5^{\prime}\right)$ triphospho( $\left.5^{\prime}\right)$ xanthosine; $\mathrm{Ap}_{4} \mathrm{~A}$,

adenosine $\left(5^{\prime}\right)$ tetraphospho $\left(5^{\prime}\right)$ adenosine; $\mathrm{Ap}_{4} \mathrm{dA}$,

adenosine $\left(5^{\prime}\right)$ tetraphospho( $\left.5^{\prime}\right)$ deoxyadenosine; $\mathrm{Ap}_{4} \mathrm{dC}$,

adenosine $\left(5^{\prime}\right)$ triphospho $\left(5^{\prime}\right)$ deoxycytidine; $\mathrm{Ap}_{4} \mathrm{ddA}$,

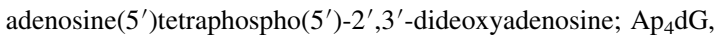

adenosine $\left(5^{\prime}\right)$ tetraphospho( $\left.5^{\prime}\right)$ deoxyguanosine; $\mathrm{Ap}_{4} \mathrm{G}$,

adenosine $\left(5^{\prime}\right)$ tetraphospho( $\left(5^{\prime}\right)$ guanosine; $\mathrm{Ap}_{4} \mathrm{~N}$,

adenosine $\left(5^{\prime}\right)$ tetraphospho( $\left.5^{\prime}\right)$ nucleoside; $\mathrm{Ap}_{4} \mathrm{X}$,

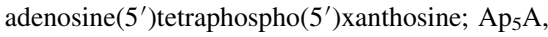

adenosine $\left(5^{\prime}\right)$ pentaphospho $\left(5^{\prime}\right)$ adenosine; ATP $\gamma \mathrm{S}$, adenosine- $5^{\prime}-\gamma$ -

thiotriphosphate; ddATP, 2',3'-dideoxyadenosine-5'-triphosphate; $\mathrm{LH}_{2}$, luciferin; $\mathrm{Np}_{\mathrm{n}} \mathrm{N}$, nucleoside (5') polyphospho(5')nucleoside; $\mathrm{P}_{3}$, tripolyphosphate; $\mathrm{P}_{4}$, tetrapolyphosphate; $\mathrm{P}_{15}$, linear-chain polyphosphate with an average chain length of $15 \pm 3 \mathrm{p}_{4} \mathrm{~A}$, adenosine- $5^{\prime}$-tetraphosphate; $\mathrm{Xp}_{4} \mathrm{X}$, xanthosine $\left(5^{\prime}\right)$ tetraphospho(5')xanthosine.

Enzymes: acetyl-CoA synthetase (EC6.2.1.1); acyl-CoA synthetase

(EC6.2.1.3); alkaline phosphatase (EC3.1.3.1); DNA ligase (AMP forming)

(EC6.5.1.1); DNA ligase (AMP-forming, NMN-forming) (EC6.5.1.2);

firefly luciferase (EC1.13.12.7); inorganic pyrophosphatase (EC3.6.1.1);

RNA ligase (EC2.7.4.3).

(Received 20 January 1999, accepted 18 February 1999) inhibitors of ATP-regulated $\mathrm{K}^{+}$channels, etc. [1] (reviewed in $[2,3])$. Interest in dinucleoside polyphosphates has increased after the discovery that the putative human tumor suppressor gene FHIT (for fragile histidine triad) encodes for a typical dinucleoside $5^{\prime}, 5^{\prime \prime \prime}-\mathrm{P}^{1}, \mathrm{P}^{3}$ triphosphate hydrolase (EC3.6.1.29) [4], an enzyme that cleaves $\mathrm{Ap}_{3} \mathrm{~A}$ to $\mathrm{AMP}$ and $\mathrm{ADP}$ [5-8]. Crystal structure of the fhit protein showing its interaction with $\mathrm{Ap}_{3} \mathrm{~A}$ has been reported $[9,10]$.

The hypothesis was put forward in 1990 that the enzymes ligases could be candidates for the synthesis of $\mathrm{Np}_{n} \mathrm{~N}$ [11]. Some ligases of the subclass EC 6.1 (as aminoacyl-tRNA synthetases) and of the subclass EC 6.2 (as acetyl-CoA synthetases and acylCoA synthetases) catalyze the synthesis of diadenosine tetraphosphate and other dinucleoside polyphosphates through the general reactions shown in Eqns (1) and (2) below [12-14]:

$$
\begin{gathered}
\mathrm{E}+\mathrm{ATP}+\mathrm{X} \leftrightarrow \mathrm{E}-\mathrm{X}-\mathrm{AMP}+\mathrm{PP}_{\mathrm{i}} \\
\mathrm{E}-\mathrm{X}-\mathrm{AMP}+\mathrm{ATP} \rightarrow \mathrm{Ap}_{4} \mathrm{~A}+\mathrm{X}+\mathrm{E}
\end{gathered}
$$

where $\mathrm{X}$ represents a free acid.

In addition, the oxidoreductase firefly luciferase (EC1.12.13.7) also catalyzes the synthesis of $\mathrm{Ap}_{4} \mathrm{~A}$ and other dinucleoside polyphosphates [15] using luciferin as cofactor and through reactions similar to 1 and 2 . These enzymes liberate pyrophosphate and use the intermediate E-acyl-AMP as donor of AMP for the synthesis of dinucleoside polyphosphates. As reaction 1 is reversible, the synthesis of $\mathrm{Ap}_{4} \mathrm{~A}$ is greatly favoured in the presence of pyrophosphatase.

The ligases belonging to the subclass EC 6.5 catalyze the formation of phosphoric ester bonds through an intermediate E-AMP. Three enzymes are recognized in this group: EC6.5.1.1 or DNA ligase (AMP forming); EC6.5.1.2 or DNA ligase (AMPforming, NMN-forming) and EC6.5.1.3 or RNA ligase. The synthesis of dinucleoside polyphosphates by T4 DNA ligase (EC6.5.1.1) has been very recently reported [16]. 
The mechanism of RNA ligases, similar to that of T4 DNA ligases [17], involves three reversible steps shown below in Eqns (3) $-(5)$.

$$
\begin{gathered}
\mathrm{E}+\mathrm{ATP} \leftrightarrow \mathrm{E}-\mathrm{AMP}+\mathrm{PP}_{\mathrm{i}} \quad(\text { Enzyme adenylylation) } \\
\mathrm{E}-\mathrm{AMP}+5^{\prime} \text {-P-RNA } \leftrightarrow \mathrm{E} \cdot \mathrm{AppRNA} \quad \text { (RNA adenylylation) }
\end{gathered}
$$

$$
\begin{aligned}
& \mathrm{E} \cdot \text { AppRNA }+3^{\prime}-\mathrm{OH}-\mathrm{RNA} \leftrightarrow \mathrm{RNA}-\mathrm{p}-R N A+\mathrm{AMP}+\mathrm{E} \\
& \quad \text { (RNA joining) }
\end{aligned}
$$

Depending on whether the $5^{\prime}$-P-RNA donor and the $3^{\prime}-\mathrm{OH}-\mathrm{RNA}$ acceptor belong to the same or different RNA molecules the reaction will be intramolecular or intermolecular, respectively. In the first case T4 ligase promotes circularization of RNA. The enzyme can use either RNA or DNA as substrates [18-22].

Here we report for the first time the ability of T4 RNA ligase to catalyze the synthesis of adenosine $5^{\prime}$-polyphosphates and of a variety of dinucleoside polyphosphates.

\section{MATERIALS AND METHODS}

\section{Materials}

T4 RNA ligase was purchased from Boehringer Mannheim (1449478; lot numbers, 84064023-08 and 84064024-08). Electrophoresis on polyacrylamide gels, in the presence of SDS, of those preparations presented a unique band (when stained with Coomassie Blue) with an apparent molecular mass of $42 \mathrm{kDa}$. The specific activities were about $1800 \mathrm{U} \cdot \mathrm{mg}^{-1}$ protein. One unit (U) is the enzyme activity required to catalyze the formation of $1 \mathrm{nmol}$ of $\left[5^{\prime}-{ }^{32} \mathrm{P}\right] \mathrm{rA}_{12-18}$ into a phosphatase-resistant form in $30 \mathrm{~min}$ at $37{ }^{\circ} \mathrm{C}$. Poly(A), sodium tripolyphosphate (5633) $\left(\mathrm{P}_{3}\right)$, hexaammonium tetrapolyphosphate $\left(\mathrm{P}_{4}\right)$ and sodium phosphate glass Type $15\left(\mathrm{P}_{15}\right)$ were from Sigma (Refs 5758 and 6003 , respectively). The purity of the polyphosphates was checked by ion-exchange chromatography essentially as described in [23]. While $\mathrm{P}_{3}$ and $\mathrm{P}_{4}$ were more than $97 \%$ and $90 \%$ pure, respectively; $\mathrm{P}_{15}$ was a mixture of at least 20 different (poly)phosphates [23]. Alkaline phosphatase (grade I) (EC 3.1.3.1), phosphodiesterase from Crotalus durissus (EC 3.1.4.1) and yeast inorganic pyrophosphatase (EC 3.6.1.1), were obtained from Boehringer Mannheim. pd(A) $)_{12-18}$ was from Pharmacia Biotech (Ref. 27-7975). [ $\alpha-{ }^{32} \mathrm{P}$ ]ATP, $3000 \mathrm{Ci} \cdot \mathrm{mmol}^{-1}$, was from Dupont NEN. TLC silica-gel fluorescent plates were from Merck. X-ray films were from Konica Corporation (Japan). Radioactively labeled nucleotides were quantified with the help of an InstantImager (Packard Instrument Co). HPLC was carried out in a Hewlett Packard chromatograph (model 1090), with a diode array detector, commanded by an HPLC ChemStation. The Hypersil ODS columns $(2.1 \times 100 \mathrm{~mm})$ or $(4.6 \times 100 \mathrm{~mm})$ were from Hewlett Packard. Ultrafiltration was performed with microconcentrators with exclusion limit membranes of $30 \mathrm{kDa}$ from Vivascience.

Inorganic pyrophosphatase (used to hydrolyze the $\mathrm{PP}_{\mathrm{i}}$ produced during the enzyme assays or the $\mathrm{PP}_{\mathrm{i}}$ contaminating $\mathrm{P}_{3}$ ) was a suspension in $3.2 \mathrm{M}$ ammonium sulfate. As ammonium sulfate was an inhibitor of the reactions here described, pyrophosphatase was desalted by ultrafiltration before use.

\section{T4 RNA ligase-AMP complex formation}

The reaction mixture $(0.02 \mathrm{~mL})$ contained $50 \mathrm{~mm}$ Tris/ $\mathrm{HCl}$ (pH 7.4), $1 \mathrm{~mm}$ dithiothreitol, $5 \mathrm{~mm} \mathrm{MgCl}_{2}, 5 \mu \mathrm{M}(0.1 \mu \mathrm{Ci})$ $\left[\alpha-{ }^{32} \mathrm{P}\right]$ ATP, $0.02 \mathrm{U}$ of desalted pyrophosphatase and, when indicated tripolyphosphate $\left(\mathrm{P}_{3}\right)$. The mixture was incubated for 15 min to remove the potential $\mathrm{PP}_{\mathrm{i}}$ contaminating the commercial preparation of $\mathrm{P}_{3}$. The formation of the E-AMP complex was initiated by addition of $2 \mathrm{U}$ of T4 RNA ligase. After $15 \mathrm{~min}$ incubation, reactions were stopped with $6.5 \mu \mathrm{L}$ of concentrated SDS sample buffer $(0.25$ м Tris/ $\mathrm{HCl}(\mathrm{pH} 6.8), 8 \%$ SDS, $40 \%$ glycerol, $240 \mathrm{~mm}$ dithiothreitol, $0.005 \%$ bromophenol blue). The mixtures were heated at $90{ }^{\circ} \mathrm{C}$ for $3 \mathrm{~min}$ and $6-\mu \mathrm{L}$ aliquots loaded onto a $12 \%$ denaturing polyacrylamide gel. The gel was stained with Coomassie Blue, dried down and the labeled enzyme-adenylate complex detected by autoradiography.

\section{Synthesis of (di)nucleoside polyphosphates by T4 RNA ligase}

Unless otherwise indicated the reaction mixtures contained $50 \mathrm{~mm}$ Tris/ $\mathrm{HCl}$ (pH 7,4), $1 \mathrm{~mm}$ dithiothreitol, $5 \mathrm{~mm} \mathrm{MgCl}_{2}$, $1 \mathrm{U} \cdot \mathrm{mL}^{-1}$ of desalted pyrophosphatase, T4 RNA ligase, ATP and other nucleotides or polyphosphates as indicated. After incubation at $30{ }^{\circ} \mathrm{C}$ the reaction mixtures were analyzed by one of the following methods.

TLC. The reaction mixtures $(0.02 \mathrm{~mL})$ contained $0.02 \mathrm{~mm}$ $\left[\alpha-{ }^{32} \mathrm{P}\right]$ ATP $(0.1 \mu \mathrm{Ci})$. Aliquots $(2 \mu \mathrm{L})$ of the reactions were taken, spotted on silica gel plates, along with standards, and developed in dioxane : ammonium hydroxide : water $(6: 1: 4$, or $6: 1: 6$ by volume). Nucleotide spots were localized with a 253-nm wavelength light and the corresponding radioactivity measured by autoradiography and/or with an InstantImager.

HPLC. Aliquots $(0.01 \mathrm{~mL})$ of the reaction mixtures (usually in a volume of $0.05-0.1 \mathrm{~mL}$ ) were transferred into $0.14 \mathrm{~mL}$ of water and kept at $95{ }^{\circ} \mathrm{C}$ for $1.5 \mathrm{~min}$. After chilling, the mixtures were filtered and a $0.05-\mathrm{mL}$ aliquot injected into a Hypersil ODS column $(2.1 \times 100 \mathrm{~mm}$ or $4.6 \times 100 \mathrm{~mm})$, as indicated. Elution was performed (for both types of columns) at a flow rate of $0.5 \mathrm{~mL} \cdot \mathrm{min}^{-1}$ with a 20-min linear gradient $(5-30 \mathrm{~mm})$ of sodium phosphate $(\mathrm{pH} \mathrm{7.5)}$, in $20 \mathrm{~mm}$ tetrabutylammonium bromide/20\% methanol (buffer A) followed, when pertinent, by a 10-min linear gradient $(30-100 \mathrm{~mm})$ of sodium phosphate (pH 7.5) in buffer A.

\section{RESULTS AND DISCUSSION}

\section{Formation of the E-AMP complex and its reaction with $\mathbf{P}_{3}$}

Formation of a E-AMP complex was observed when T4 RNA ligase was incubated with $[\alpha-32 \mathrm{P}]$ ATP. As expected, the complex migrated on SDS/PAGE in a position corresponding to a molecular mass of about $45 \mathrm{kDa}$ [19] (Fig. 1a). In those experimental conditions (i.e. absence of $\mathrm{PP}_{\mathrm{i}}$ because of the presence of pyrophosphatase), the AMP moiety of the complex reacted with $\mathrm{P}_{3}$ in a concentration dependent manner (Fig. 1b).

\section{Synthesis and characterization of $\mathrm{Ap}_{4} \mathrm{~A}$ catalyzed by $\mathrm{T} 4$ RNA ligase. Dependence on time and influence of pyrophosphatase.}

The fate of AMP from the E-AMP complex was followed by incubating the enzyme with $\left[\alpha-{ }^{32} \mathrm{P}\right] \mathrm{ATP}$, in the absence or presence of pyrophosphatase. The reaction was followed by TLC (Fig. 2a,b). The radioactivity under the ATP spot was gradually displaced towards a new radioactive compound co-migrating with a standard of $\mathrm{Ap}_{4} \mathrm{~A}$. In these experimental conditions the reaction was linear during $10 \mathrm{~min}$ (Fig. 2c). The synthesis of $\mathrm{Ap}_{4} \mathrm{~A}$ decreased with time of incubation, mainly 
a

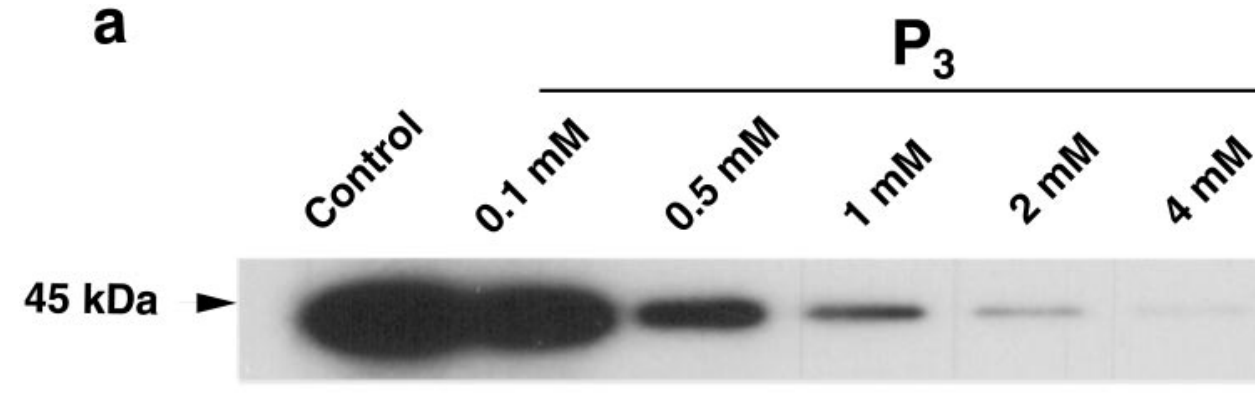

b

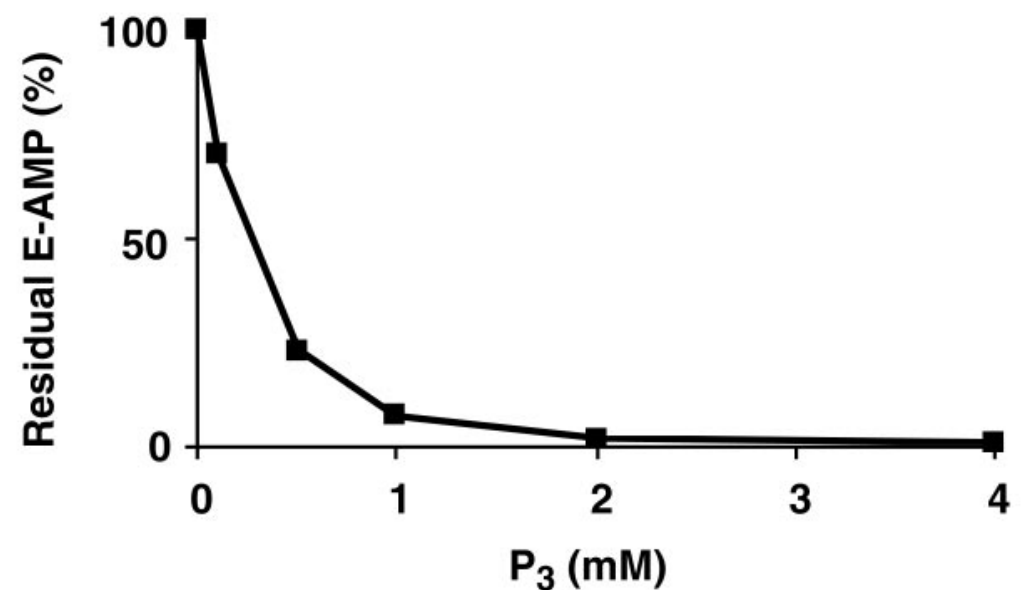

Fig. 1. Inhibition of T4 RNA ligaseadenylyl complex formation by tripolyphosphate $\left(\mathbf{P}_{\mathbf{3}}\right)$. (a) The enzyme was incubated with $\left[\alpha-{ }^{32} \mathrm{P}\right] \mathrm{ATP}$ in the absence or presence of increasing concentrations of $\mathrm{P}_{3}$ as indicated, and subjected to SDS/PAGE as described in Materials and methods. The relevant portion of the autoradiogram is shown. The size (in $\mathrm{kDa}$ ) of co-electrophroresed marker proteins are indicated by the arrow at the left. (b) The inhibition (\%) of the adenylylation of the enzyme by $\mathrm{P}_{3}$ was quantified in an InstantImager. because of the low ATP concentration in the mixture. The formation of the new spot, corresponding to $\mathrm{Ap}_{4} \mathrm{~A}$ was stimulated by desalted pyrophosphatase (Fig. 2a,b). The initial rates of synthesis of $\mathrm{Ap}_{4} \mathrm{~A}$ in the absence and presence of pyrophosphatase were 0.4 and $1.2 \mathrm{nmol} \cdot \mathrm{min}^{-1} \cdot \mathrm{mg}^{-1}$ protein, respectively. In the absence of pyrophosphatase, the calculated equilibrium constant of the reaction $2 \mathrm{ATP} \leftrightarrow \mathrm{Ap}_{4} \mathrm{~A}+\mathrm{PP}_{\mathrm{i}}$ was 0.005 .

The synthesis and characterization of $\mathrm{Ap}_{4} \mathrm{~A}$ by T4 RNA ligase was approached in a different reaction mixture $(0.05 \mathrm{~mL})$ containing $2 \mathrm{~mm}$ ATP, $10 \mathrm{U}$ of ligase, and other conditions as described in Materials and methods. After overnight incubation, the reaction products were analyzed by HPLC. Most of the ATP was transformed into a new compound, $\mathrm{Ap}_{4} \mathrm{~A}$. Minor peaks corresponding to $\mathrm{AMP}, \mathrm{ADP}$ and to a presumptive $\mathrm{Ap}_{3} \mathrm{~A}$ were also observed (Fig. $3 \mathrm{a}$ ). $\mathrm{Ap}_{4} \mathrm{~A}$ was characterized as follows. It co-eluted with an $\mathrm{Ap}_{4} \mathrm{~A}$ standard; treatment of the mixture with alkaline phosphatase $\left(1 \mu \mathrm{g}\right.$ for $2 \mathrm{~h}$ at $\left.37{ }^{\circ} \mathrm{C}\right)$ degraded AMP and ADP to adenosine while keeping unaltered the chromatographic peaks corresponding to the presumptive $\mathrm{Ap}_{4} \mathrm{~A}$ and $\mathrm{Ap}_{3} \mathrm{~A}$ (Fig. 3b). After inactivation of the phosphatase, the reaction mixture was further treated with phosphodiesterase $(0.4 \mu \mathrm{g})$ for 10, 30, 60 and $120 \mathrm{~min}$ (Fig. 3c-f). The main products formed as a result of $\mathrm{Ap}_{4} \mathrm{~A}$ hydrolysis were ATP and AMP. ADP was the product of the hydrolysis of the presumptive $\mathrm{Ap}_{3} \mathrm{~A}$ by the phosphodiesterase.

\section{$K_{\mathrm{m}}$ value for GTP in the synthesis of $\mathrm{Ap}_{4} \mathrm{G}$}

The experiments shown in Figs 2 and 3 indicated that ATP behaves both as donor of AMP for the formation of E-AMP and acceptor of AMP for the formation of $\mathrm{Ap}_{4} \mathrm{~A}$. The $K_{\mathrm{m}}$ value for ATP in the first step of the reaction (formation of the E-AMP complex) is around $10 \mu \mathrm{M}$ [18]. In our experience with other enzymes synthesizing $\mathrm{Ap}_{4} \mathrm{~A}$ [13-15], the second step (reaction 2) is rather unspecific and any nucleoside triphosphate (NTP) can be acceptor of AMP, acting with a high $K_{\mathrm{m}}$ value. For these reasons, GTP was tested as acceptor of AMP, using labeled ATP as donor. The $K_{\mathrm{m}}$ value for GTP in the synthesis of $\mathrm{Ap}_{4} \mathrm{G}$ was determined in the presence of fixed $(0.02 \mathrm{~mm})\left[\alpha-{ }^{32} \mathrm{P}\right]$ ATP and variable $(0.1 \mathrm{~mm}$ to $4 \mathrm{~mm})$ GTP concentrations. In these conditions, the $K_{\mathrm{m}}$ value found for GTP was about $1.2 \mathrm{~mm}$ (result not shown), and the rate of synthesis $\left(k_{\text {cat }}\right)$ of $\mathrm{Ap}_{4} \mathrm{G}$ was $0.017 \mathrm{~s}^{-1}$.

\section{Effect of pH}

The effect of $\mathrm{pH}$ on the rate of synthesis of a dinucleoside tetraphosphate $\left(\mathrm{Ap}_{4} \mathrm{G}\right)$ was determined in reaction mixtures containing $0.02 \mathrm{~mm}\left[\alpha-{ }^{32} \mathrm{P}\right] \mathrm{ATP}(0.1 \mu \mathrm{Ci}), 4 \mathrm{~mm}$ GTP, and $0.8 \mathrm{U} \mathrm{T} 4 \mathrm{RNA}$ ligase and $50 \mathrm{~mm}$ (each) of the following buffers: $\mathrm{Mes} / \mathrm{KOH}$ (for $\mathrm{pH}$ values of 5.5, 6.0, 6.4, 6.7); Hepes/ $\mathrm{KOH}$ (for $\mathrm{pH}$ values of 6.7, 7.2, 7.6), Tris/ $\mathrm{HCl}$ (for $\mathrm{pH}$ values of $7.4,8$ ). Aliquots were taken after 15 and 30 min incubation at $30{ }^{\circ} \mathrm{C}$ and analyzed by TLC. The reaction rate increased steadily from a $\mathrm{pH}$ value of 6.5 up to a maximum at $\mathrm{pH} 7.4$. Beyond this point the enzyme activity decreased. At $\mathrm{pH} 8.0$, the enzyme activity was around $70 \%$ of the maximum.

\section{Substrate specificity}

The following aspects of the substrate specificity of T4 RNA ligase were studied in the context of the synthesis of (di)nucleoside polyphosphates.

Nucleotides able to form an E-NMP complex (NMP = nucleoside 5'-monophosphate). This was approached indirectly according to the ability to form $\mathrm{p}_{4} \mathrm{~N}$ in the presence of $0.5 \mathrm{~mm} \mathrm{NTP}+3 \mathrm{~mm} \mathrm{P}_{3}$. The relative rates found were: ATP (100), dATP (6), CTP $=$ GTP $(<1)$. These results are in 


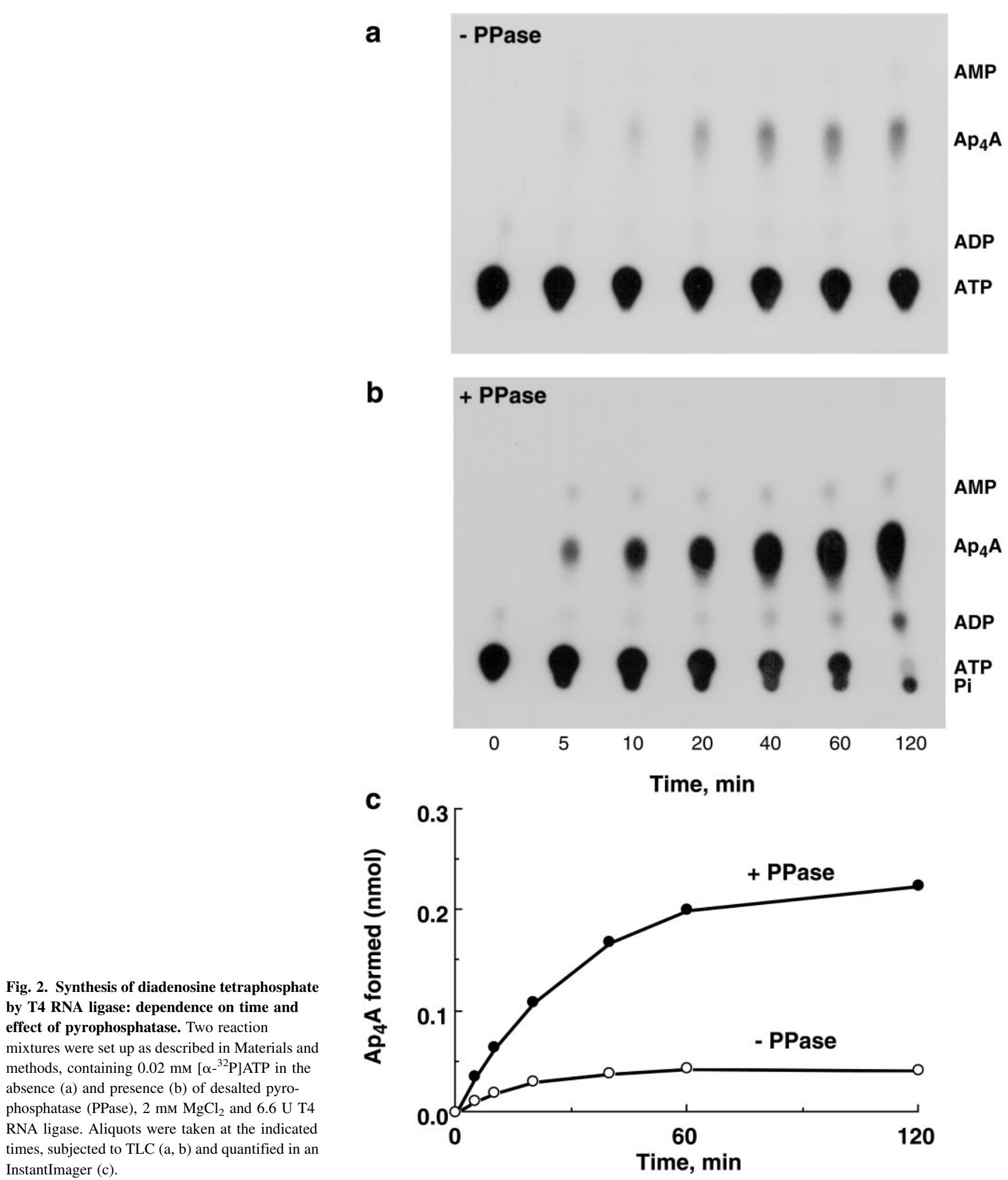

Fig. 2. Synthesis of diadenosine tetraphosphat by T4 RNA ligase: dependence on time an mixtures were set up as described in Materials and methods, containing $0.02 \mathrm{mM}\left[\alpha-{ }^{32} \mathrm{P}\right] \mathrm{ATP}$ in the absence (a) and presence (b) of desalted pyrophosphatase (PPase), $2 \mathrm{mM} \mathrm{MgCl}_{2}$ and $6.6 \mathrm{U} \mathrm{T} 4$ InstantImager (c).
AMP

$\mathrm{Ap}_{4} \mathrm{~A}$

ADP

ATP

AMP

$\mathrm{Ap}_{4} \mathrm{~A}$

ADP

ATP

Pi

Time, min agreement with previous results indicating that ATP is the preferred substrate for the RNA joining reaction [18].

The ability of $3 \mathrm{~mm} P_{3}$ or $P_{4}$ or $P_{15}$ to act as adenylyl acceptors in the presence of $1 \mathrm{~mm}$ ATP was measured by $H P L C$. In a control mixture in the absence of polyphosphate, transformation of ATP into $\mathrm{Ap}_{4} \mathrm{~A}$ was observed (Fig. 4A,a). In the presence of ATP $+\mathrm{P}_{3}$, synthesis of $\mathrm{p}_{4} \mathrm{~A}, \mathrm{Ap}_{4} \mathrm{~A}$ and of very small amounts of $\mathrm{Ap}_{5} \mathrm{~A}$ took place (Fig. 4A,b), reflecting the following set of reactions: ATP $+\mathrm{ATP} \rightarrow \mathrm{Ap}_{4} \mathrm{~A} ; \mathrm{ATP}+\mathrm{P}_{3} \rightarrow$ $\mathrm{p}_{4} \mathrm{~A}$; and $\mathrm{p}_{4} \mathrm{~A}+\mathrm{ATP} \rightarrow \mathrm{Ap}_{5} \mathrm{~A}$. With $\mathrm{P}_{4}$ as cofactor, only minor quantities of $\mathrm{p}_{5} \mathrm{~A}$, along with $\mathrm{Ap}_{4} \mathrm{~A}$, were obtained (Fig. $4 \mathrm{~A}, \mathrm{c}$ ). 
The commercial mixture of polyphosphates described as $\mathrm{P}_{15}$ was not a substrate for the reaction; in fact, these higher polyphosphates behaved as inhibitors of the reaction as no appreciable synthesis of $\mathrm{Ap}_{4} \mathrm{~A}$ was observed (Fig. 4A,d). The identity of the synthesized $\mathrm{p}_{4} \mathrm{~A}$ was investigated in an aliquot of the reaction mixture containing ATP $+\mathrm{P}_{3}$ (Fig. $\left.4 \mathrm{~B}, \mathrm{a}\right)$. The presumptive $\mathrm{p}_{4} \mathrm{~A}$ : (a) eluted with a standard of $\mathrm{p}_{4} \mathrm{~A}$; (b) was degraded by alkaline phosphatase to adenosine (and inosine, as a result of the adenosine deaminase contaminating the commercial preparations of alkaline phosphatase) (Fig. 4B,b); and (c) was hydrolyzed to AMP following treatment with snake venom phosphodiesterase (Fig. 4B,c).

Nucleotides as acceptors of AMP from the E-AMP complex. The $K_{\mathrm{m}}$ value described for ATP in the enzyme adenylylation reaction was $12 \mu \mathrm{M}$ [18]. The $K_{\mathrm{m}}$ value for ATP as acceptor of AMP was determined in the presence of $0.5,1,2,4$ and $6 \mathrm{mM}$ ATP and fixed $(1 \mathrm{mM})$ free $\mathrm{Mg}^{2+}$. In these conditions the $K_{\mathrm{m}}$ found for ATP was $1.25 \mathrm{~mm}$ and the $k_{\text {cat }}$ for $\mathrm{Ap}_{4} \mathrm{~A}$ synthesis was $0.055 \mathrm{~s}^{-1}$. Hence, the synthesis of $\mathrm{Ap}_{4} \mathrm{~N}$ was approached in the presence of low concentration, $0.02 \mathrm{~mm}$, of $\left[\alpha-{ }^{32} \mathrm{P}\right] \mathrm{ATP}$ (enough to form the E-AMP complex, but only marginally enough to form $\mathrm{Ap}_{4} \mathrm{~A}$ ), $0.8 \mathrm{U}$ of T4 RNA ligase and $4 \mathrm{~mm}$ each of XTP, dGTP, GTP, dCTP, CTP, ADP, ddATP. After 15 min incubation, the products formed were separated by TLC and the radioactivity counted. The relative rates of synthesis measured for the corresponding dinucleotides were, respectively: $\mathrm{Ap}_{4} \mathrm{X}$ (100); $\mathrm{Ap}_{4} \mathrm{dG}$ (74); $\mathrm{Ap}_{4} \mathrm{G}$ (49); $\mathrm{Ap}_{4} \mathrm{dC}(23) ; \mathrm{Ap}_{4} \mathrm{C}$ (9); $\mathrm{Ap}_{3} \mathrm{~A}$ (5); $\mathrm{Ap}_{4} \mathrm{ddA}(1)$. In the presence of $0.02 \mathrm{~mm}$ ATP and $4 \mathrm{~mm} \mathrm{P}_{3} \mathrm{p}_{4} \mathrm{~A}$ was formed at a rate about double of that obtained for $\mathrm{Ap}_{4} \mathrm{X}$. The identity of these dinucleotides was assessed by their insensitivity to alkaline phosphatase, position in the TLC plate and, when possible, by their UV spectra (see below).

ATP $\gamma S$ as a substrate of T4 RNA ligase. Because of its molecular characteristics, ATP $\gamma \mathrm{S}$ has been widely used as substrate of firefly luciferase using luciferin (LH2) as cofactor [15]. ATP $\gamma \mathrm{S}$ is a good adenylyl donor for formation of the E- $\mathrm{LH}_{2}-$ AMP complex (as it contains an intact $\alpha$-phosphate within a $\mathrm{P}_{3}$ chain) and a poor adenylyl acceptor (as it does not have an intact terminal $\mathrm{PP}_{\mathrm{i}}$ ). Because of these properties, this nucleotide has been used for the selective synthesis of $\mathrm{Ap}_{4} \mathrm{~N}$ by luciferase using ATP $\gamma S$ and NTP (good AMP acceptors). Based on the above, $\mathrm{ATP} \gamma \mathrm{S}$ was tested as substrate of T4 RNA ligase, using three reaction mixtures containing $2 \mathrm{~mm}$ ATP; ATP + XTP (2 mM each) or ATP $\gamma \mathrm{S}+$ XTP (2 mM each) (Fig. 5). In the first case (considered as a control) complete conversion of ATP into $\mathrm{Ap}_{4} \mathrm{~A}$ took place; small amounts of a presumptive $\mathrm{Ap}_{3} \mathrm{~A}$ were also observed (Fig. 5a). Synthesis of $\mathrm{Ap}_{4} \mathrm{~A}, \mathrm{Ap}_{4} \mathrm{X}$ and residual

Fig. 3. Synthesis and characterization of $\mathrm{Ap}_{\mathbf{4}} \mathrm{A}$ by $\mathrm{T} 4 \mathrm{RNA}$ ligase. (a) $\mathrm{A}$ reaction mixture $(0.05 \mathrm{~mL})$ containing $10 \mathrm{U}$ of RNA ligase and $2 \mathrm{~mm}$ unlabeled ATP was incubated overnight and an aliquot $(0.01 \mathrm{~mL})$ subjected to HPLC as described in the text. Peaks corresponding to AMP, ADP and presumptive $\mathrm{Ap}_{4} \mathrm{~A}$ and $\mathrm{Ap}_{3} \mathrm{~A}$ were detected. (b) Another aliquot $(0.04 \mathrm{~mL})$ of the reaction mixture was treated with $1 \mu \mathrm{g}$ of alkaline phosphatase for $2 \mathrm{~h}$, heated in boiling water for $90 \mathrm{~s}$, chromatographed and analyzed by HPLC. (using a Hypersil ODS column, $2.1 \times 100 \mathrm{~mm}$ ). The peaks corresponding to AMP and ADP were transformed into adenosine while the presumptive $\mathrm{Ap}_{4} \mathrm{~A}$ and $\mathrm{Ap}_{3} \mathrm{~A}$ remain unchanged. The remaining mixture $(0.03 \mathrm{~mL})$ was treated with snake venom phosphodiesterase $(0.4 \mu \mathrm{g})$ for 10 (c), 30 (d), 60 (e) and 120 (f) min and analyzed by HPLC in the same conditions as above. AP, alkaline phosphatase; PDE, snake venom phosphodiesterase. The numbers on top of the peaks correspond to the following compounds: (1) AMP; (2) ADP; (3) $\mathrm{Ap}_{3} \mathrm{~A}$; (4) $\mathrm{Ap}_{4} \mathrm{~A}$; (5) Ado; (6) ATP.
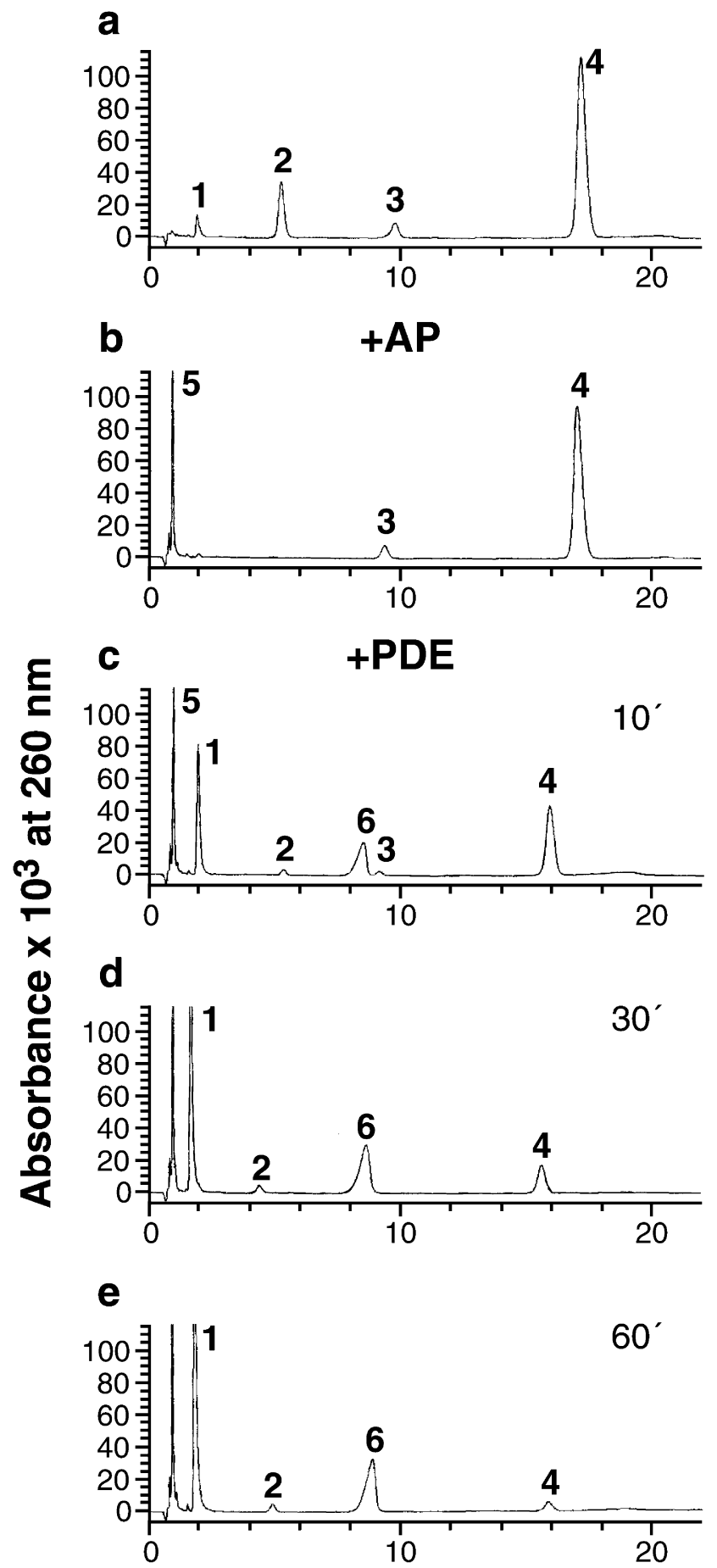

f

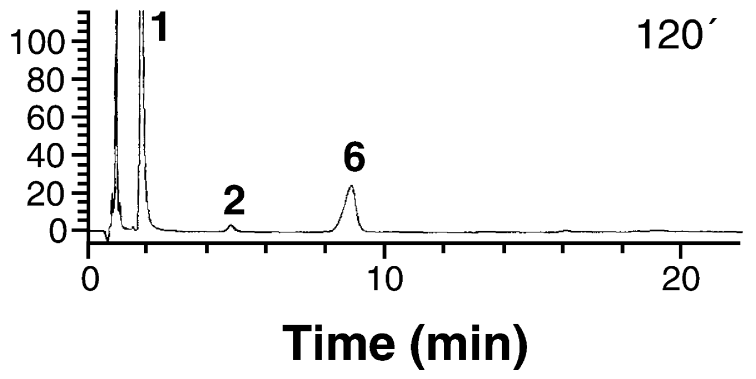




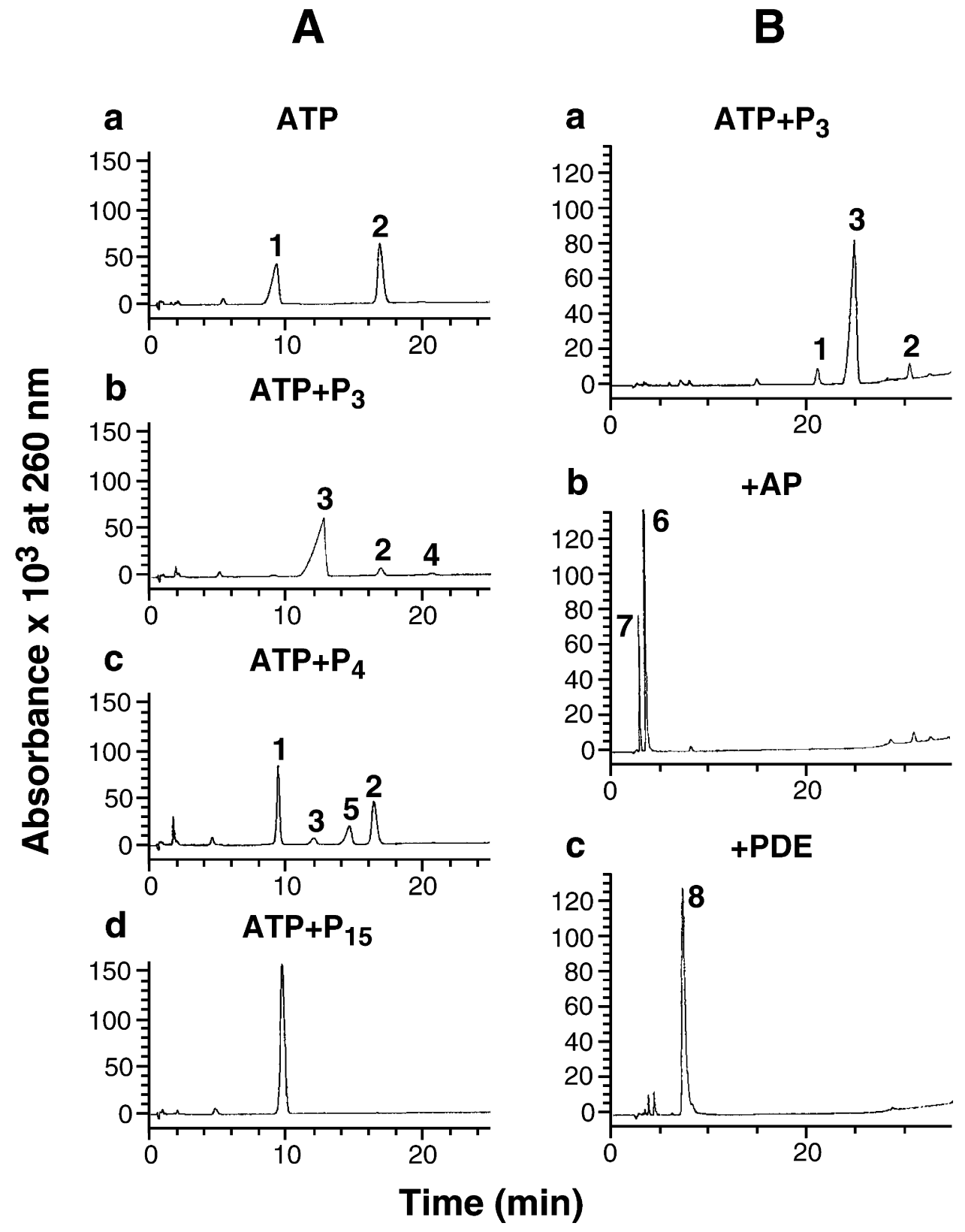

Fig. 4. Polyphosphates as substrates of T4 RNA ligase. (A) The enzyme was incubated in the presence of 1 mm ATP, desalted pyrophosphatase and in the absence (a) or presence of $3 \mathrm{~mm}$ each of $\mathrm{P}_{3}$ (b); $\mathrm{P}_{4}$ (c) or $\mathrm{P}_{15}$ (d). After overnight incubation at room temperature, the mixtures were analyzed by HPLC (using a Hypersil ODS column, $2.1 \times 100 \mathrm{~mm}$ ). (B) Two aliquots of the reaction mixture (a) were treated either with alkaline phosphatase $\left(5 \mu \mathrm{g}, 2 \mathrm{~h}, 37^{\circ} \mathrm{C}\right)(\mathrm{b})$ or with snake venom phosphodiesterase $\left(1 \mu \mathrm{g}, 2 \mathrm{~h}, 37^{\circ} \mathrm{C}\right)(\mathrm{c})$. All three samples were analyzed by HPLC (using a Hypersil ODS column, $4.6 \times 100 \mathrm{~mm}$ ). AP alkaline phosphatase; PDE phosphodiesterase. The numbers on top of the peaks correspond to the following compounds: (1) ATP; (2) $\mathrm{Ap}_{4} \mathrm{~A}$; (3) $\mathrm{p}_{4} \mathrm{~A}$; (4) $\mathrm{Ap}_{5} \mathrm{~A}$; (5) $\mathrm{p}_{5} \mathrm{~A}$; (6) adenosine; (7) inosine (8) AMP.

amounts of $\mathrm{Ap}_{3} \mathrm{~A}$ and $\mathrm{Ap}_{3} \mathrm{X}$ were observed in the presence of ATP and XTP (Fig. 5c); the results were as expected, i.e. once the E-AMP complex was formed, the adenylyl residue could be transferred to either ATP (with formation of $\mathrm{Ap}_{4} \mathrm{~A}$ ) or to XTP (with formation of $\mathrm{Ap}_{4} \mathrm{X}$ ). Pyrophosphatase can hydrolyze inorganic thiopyrophosphate (generated from ATP $\gamma \mathrm{S}$ ) to $\mathrm{Pi}+$ thiophosphate [24] thus preventing its reaction with the E-AMP complex. In the mixture containing ATP $\gamma S$ and XTP only a small amount of $\mathrm{Ap}_{4} \mathrm{X}$ was synthesized (Fig. 5b), reflecting two facts: (a) XTP was not donor for the formation of an hypothetical E-XMP, as formation of $\mathrm{Xp}_{4} \mathrm{X}$ would be expected in that case; (b) ATP $\gamma \mathrm{S}$ was a poor donor for the formation of E-AMP.
The nature of the synthesized products was analyzed in several ways: (a) by their chromatographic position - in our experimental conditions, xanthine derivatives are retarded with respect to adenine derivatives of equal structure and number of phosphates; (b) by treatment with alkaline phosphatase of the mixture containing ATP and XTP - only peaks corresponding to $\mathrm{Ap}_{4} \mathrm{X}, \mathrm{Ap}_{4} \mathrm{~A}$ and to presumptive $\mathrm{Ap}_{3} \mathrm{X}$ remained (Fig. 5d); and (c) by UV absorption spectra of $\mathrm{Ap}_{4} \mathrm{~A}$ (or $\mathrm{Ap}_{3} \mathrm{~A}$ ) comparared with that of $\mathrm{Ap}_{4} \mathrm{X}$ (or $\mathrm{Ap}_{3} \mathrm{X}$ ) or XTP (Fig. 5e).

The relative amount of $\mathrm{Ap}_{4} \mathrm{X}$ synthesized in the presence of $(\mathrm{ATP}+\mathrm{XTP})$ or $(\mathrm{ATP} \gamma \mathrm{S}+\mathrm{XTP})$ was 100 and 10, respectively. 
The potential of ATP $\gamma \mathrm{S}$ to adenylylate RNA ligase was further assayed in the experiment described below.

\section{Synthesis of diadenosine triphosphate catalyzed by T4 RNA} ligase

A clue to the synthesis of $\mathrm{Ap}_{3} \mathrm{~A}$ by T4 RNA ligase was obtained in previous assays (Figs $3 \mathrm{~b}$ and 5a). However, due to the recent interest of diadenosine triphosphate as substrate of a potential tumor suppressor gene (the FHIT gene [4-7]), the synthesis of $\mathrm{Ap}_{3} \mathrm{~A}$ was further assessed by HPLC in reaction mixtures containing $1 \mathrm{~mm}$ ATP $+2 \mathrm{~mm}$ ADP (Fig. 6a) or $2 \mathrm{~mm}$ ATP $\gamma \mathrm{S}$ $+2 \mathrm{~mm}$ ADP (Fig. 6b). After an overnight incubation, the mixtures were treated with alkaline phosphatase (Fig. 6c,d), and the remaining peaks corresponded to $\mathrm{Ap}_{3} \mathrm{~A}$ and $\mathrm{Ap}_{4} \mathrm{~A}$. The nature of the presumptive $\mathrm{Ap}_{3} \mathrm{~A}$ was further confirmed by treatment with dinucleoside triphosphatase (purified from rat liver [6]), which gave ADP and AMP as products of hydrolysis of $\mathrm{Ap}_{3} \mathrm{~A}$ (results not shown).

In the presence of $1 \mathrm{~mm}$ ATP $+2 \mathrm{~mm}$ ADP (Fig. 6a), the relative amounts of $\mathrm{Ap}_{4} \mathrm{~A}$ and $\mathrm{Ap}_{3} \mathrm{~A}$ formed were 100 and 130 , respectively. As above, ATP $\gamma \mathrm{S}$ was not good donor of AMP for the synthesis of $\mathrm{Ap}_{3} \mathrm{~A}$ from $\mathrm{ADP}$ : the $\mathrm{Ap}_{3} \mathrm{~A}$ synthesized in the presence of ATP $\gamma \mathrm{S}+\mathrm{ADP}$ was only $25 \%$ of that formed in the presence of ATP + ADP.

\section{Inhibition of the synthesis of $\mathrm{Ap}_{4} \mathrm{G}$ by $\mathrm{T} 4 \mathrm{RNA}$ ligase donors}

In the terminology at use for T4 RNA ligase [19,25], the 5 '-phosphoryl and the 3 '-OH terminated portions of RNA (or similar molecules) are called the RNA donor and the RNA acceptor, respectively (shown in italics). Three active sites are considered in the enzyme: the ATP site, the donor site and the acceptor site. Although the term donor refers more properly to the potentiality of being RNA donor, the 5'-P end of RNA is firstly acting as AMP acceptor from the E-AMP complex. Only after formation of E·AppRNA takes place, the RNA behaves as donor. In a strict sense, the term acceptor could be applied equally well to the modified $5^{\prime}-\mathrm{P}$ end of RNA, as this end can also be viewed as accepting the $3^{\prime}-\mathrm{OH}$ terminal RNA. It seems to us curious that this terminology has not been developed for the very similar reactions catalyzed by T4 DNA ligase. In the context of this work, it seems more appropriate to name the three reactions catalyzed by T4 RNA ligase as: enzyme adenylylation, RNA adenylylation and RNA joining.

The substrate specificity of the ATP binding site can be directly determined [18] and this work. The substrate specificity of the 5'-P-RNA donor in the RNA adenylylation reaction [4] has been indirectly determined by studying the overall RNA joining reaction [19]. A ribonucleoside $3^{\prime}, 5^{\prime}$-bisphosphate ( $\mathrm{pCp}>\mathrm{pAp}>\mathrm{pA} 2^{\prime} \mathrm{p}$ ) was much better donor than a nucleoside $5^{\prime}$-monophosphate (pA or $\mathrm{pC}$ ). Related to the mechanism of reaction of this enzyme, the synthesis of $\mathrm{p}_{4} \mathrm{~A}$ (from ATP and $\mathrm{P}_{3}$ ) or $\mathrm{Ap}_{4} \mathrm{~N}$ (from ATP and NTP) can be interpreted in two ways.

Fig. 5. ATP $\gamma \mathrm{S}$ as substrate of T4 RNA ligase. Among other components (see Materials and methods), the reaction mixtures contained $10 \mathrm{U}$ RNA ligase and: (a) $2 \mathrm{~mm}$ ATP; (b) $2 \mathrm{~mm}$ ATP $\gamma \mathrm{S}+2 \mathrm{~mm}$ XTP; (c) $2 \mathrm{~mm}$ ATP +2 mм XTP. After an overnight incubation, mixture (c) was further treated with $1 \mu \mathrm{g}$ alkaline phosphatase for $2 \mathrm{~h}$ at $37{ }^{\circ} \mathrm{C}(\mathrm{d})$. Analysis was performed by HPLC. UV spectra corresponding to $\mathrm{Ap}_{4} \mathrm{~A}$ (4), or $\mathrm{Ap}_{4} \mathrm{X}$ (8) or XTP (7) are indicated in part (e) of the Fig. The spectra of the presumptive $\mathrm{Ap}_{3} \mathrm{~A}$; (3) and $\mathrm{Ap}_{3} \mathrm{X}(9)$ were identical to the spectra of $\mathrm{Ap}_{4} \mathrm{~A}(4)$ and $\mathrm{Ap}_{4} \mathrm{X}$ (8), respectively. The numbers on top of the peaks correspond to the following compounds: (1) AMP; (2) ADP; (3) $\mathrm{Ap}_{3} \mathrm{~A}$; (4) $\mathrm{Ap}_{4} \mathrm{~A}$; (5) XDP; (6) ATP $\gamma$ S; (7) XTP; (8) $\mathrm{Ap}_{4} \mathrm{X}$; (9) $\mathrm{Ap}_{3} \mathrm{X}$; (10) Ado + Ino.

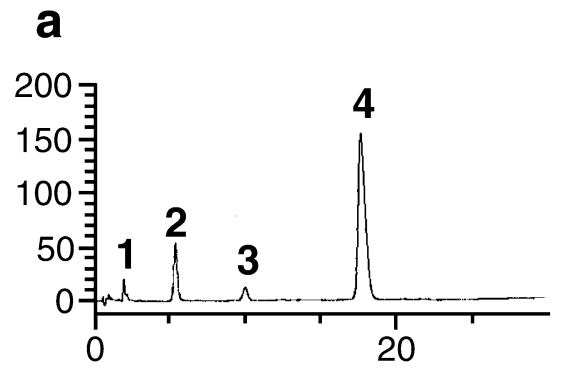

b

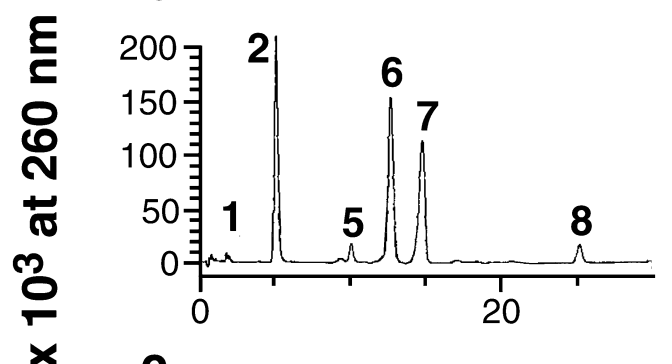

C

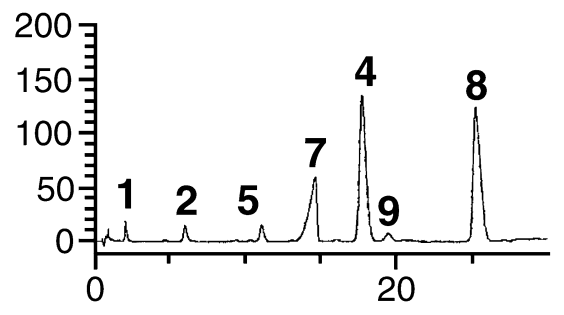

d

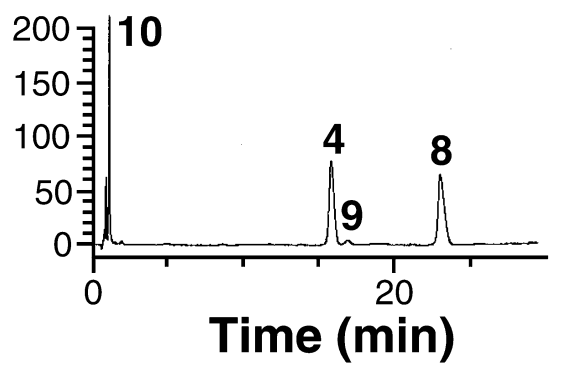

e

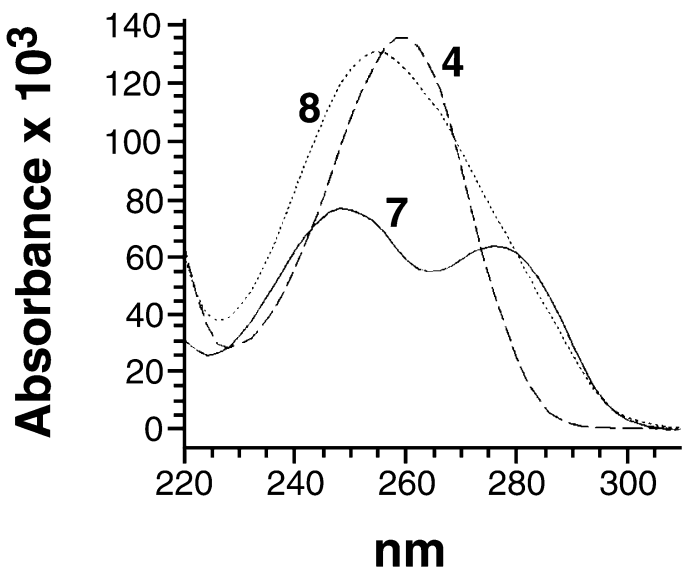




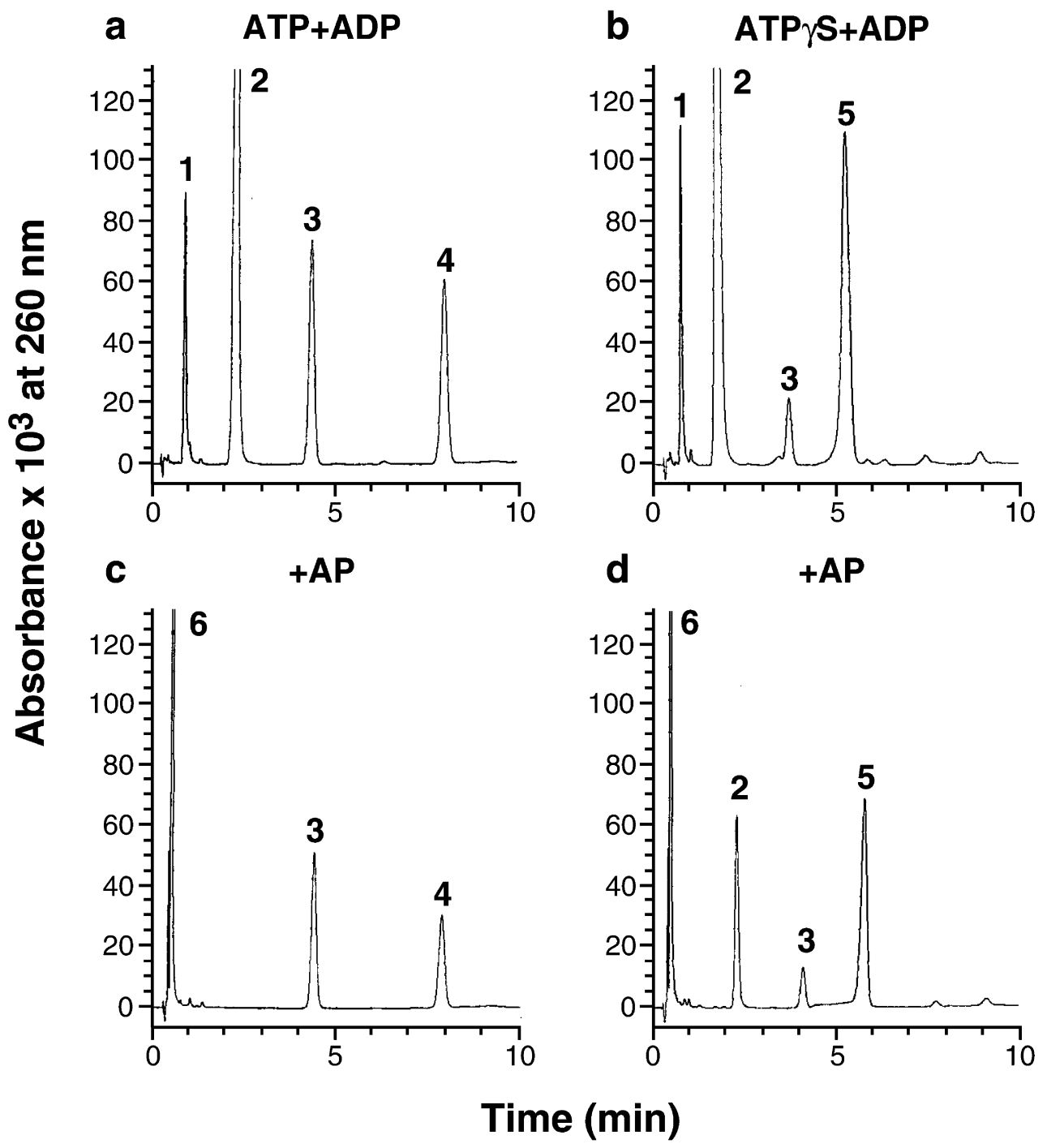

Fig. 6. Synthesis of $\mathbf{A p}_{3} \mathbf{A}$ catalyzed by $\mathbf{T} 4$ RNA ligase. Among other components (see Materials and methods), the reaction mixtures contained $10 \mathrm{U}$ RNA ligase and: (a) $1 \mathrm{~mm}$ ATP $+2 \mathrm{~mm}$ (ADP); (b) $2 \mathrm{~mm}$ ATP $\gamma \mathrm{S}+2 \mathrm{~mm}$ ADP. After overnight incubation, aliquots of the mixtures were treated with $1 \mu \mathrm{g}$ of alkaline phosphatase (c and d, respectively), and analyzed by HPLC. The numbers on top of the peaks correspond to the following compounds: (1) AMP; (2) ADP; (3) $\mathrm{Ap}_{3} \mathrm{~A}$; (4) $\mathrm{Ap}_{4} \mathrm{~A}$; (5) ATP $\gamma \mathrm{S} ;(6)$ Ado + Ino.

Firstly, the formation of these compounds simply implies reversal of the enzyme adenylylation reaction (reaction 3), i.e. the E-AMP complex transfers the AMP moiety to $\mathrm{P}_{2}, \mathrm{P}_{3}, \mathrm{p}_{3} \mathrm{~A}$, $p_{3} G, p_{2} A$, etc., with formation of ATP, $p_{4} A, A p_{4} A, A p_{4} G, A p_{3} A$, etc., respectively, without apparently any need of the donor substrate or donor site of the enzyme. Secondly, the same reactions could take place after location of $\mathrm{P}_{3}$ (or NTP) in the donor site of the enzyme, and are adenylated there by the E-AMP complex. The substrate specificity of the donor site, as studied in the RNA joining reaction does not support this possibility [19].

Considering either of these two alternatives, a true donor of the enzyme, susceptible to being adenylylated, could be expected to be an inhibitor of the synthesis of $\mathrm{Ap}_{4} \mathrm{~A}$. Variable concentrations (0.01-0.25 mM) of RNA donors (pCp, pAp, $\mathrm{pA} 2^{\prime} \mathrm{p}$ ) were tested as inhibitors of the synthesis of $\mathrm{Ap}_{4} \mathrm{~A}$ at a fixed $(0.02 \mathrm{~mm})\left[\alpha-{ }^{32} \mathrm{P}\right] \mathrm{ATP}$ concentration (Fig. 7). The reaction mixtures were analyzed by TLC. Under our experimental conditions (see Materials and methods), $\mathrm{Ap}_{4} \mathrm{~A}$ and the presumptively synthesized $\mathrm{Ap}_{2} \mathrm{Cp}, \mathrm{Ap}_{2} \mathrm{Ap}$, and $\mathrm{Ap}_{2} \mathrm{~A} 2$ ' $\mathrm{p}$ migrated in the same position (results not shown). Treatment with alkaline phosphatase before separation by TLC of the products formed, allowed the separation of $\mathrm{Ap}_{4} \mathrm{~A}$ from $\mathrm{Ap}_{2} \mathrm{C}$ and $\mathrm{Ap}_{2} \mathrm{~A}$. The results obtained with $\mathrm{pAp}$ as inhibitor of the synthesis of $\mathrm{Ap}_{4} \mathrm{~A}$ are shown in Fig. 7a. Similar experimental evidence was obtained with $\mathrm{pCp}$ and $\mathrm{pA} 2$ 'p (results not shown). From these experiments, the inhibition of the synthesis of $\mathrm{Ap}_{4} \mathrm{~A}$ by the three RNA donors tested was calculated (Fig. 7b). The best inhibitor of the synthesis of $\mathrm{Ap}_{4} \mathrm{~A}$ was $\mathrm{pCp}$ followed by $\mathrm{pAp}$ and $\mathrm{pA} 2$ ' $\mathrm{p}$, in good correlation with their effectiveness as substrate donors of T4 RNA ligase [19].

In a similar experiment, a fixed concentration $(0.02 \mathrm{~mm})$ of $\mathrm{pCp}, \mathrm{pAp}, \mathrm{pA} 2$ ' $\mathrm{p}$ was added to reaction mixtures containing $0.02 \mathrm{~mm}\left[\alpha-{ }^{32} \mathrm{P}\right] \mathrm{ATP}$. In these conditions, the initial rates of synthesis of $\mathrm{Ap}_{2} \mathrm{Cp}, \mathrm{Ap}_{2} \mathrm{Ap}$ and $\mathrm{Ap}_{2} \mathrm{~A} 2$ 'p were 12.5, 3.5 and $0.15 \mathrm{nmol} \cdot \mathrm{min}^{-1} \cdot \mathrm{mg}^{-1}$ protein, respectively, whereas the initial rate of synthesis of $\mathrm{Ap}_{4} \mathrm{~A}$ was 1.06 (with $\mathrm{pCp}$ and $\mathrm{pAp}$ ) and $1.2 \mathrm{nmol} \cdot \mathrm{min}^{-1} \cdot \mathrm{mg}^{-1}$ (with $\mathrm{pA} 2^{\prime} \mathrm{p}$ ). In the absence of added nucleoside bisphosphate, the rate of synthesis of $\mathrm{Ap}_{4} \mathrm{~A}$ from ATP was $1.25 \mathrm{nmol} \cdot \mathrm{min}^{-1} \cdot \mathrm{mg}^{-1}$. Altogether, these results are in agreement with those presented in Fig. 7. On the other side, dephosphorylated poly(A) $(2,6$, and $20 \mu \mathrm{g})$ did not have an 
a
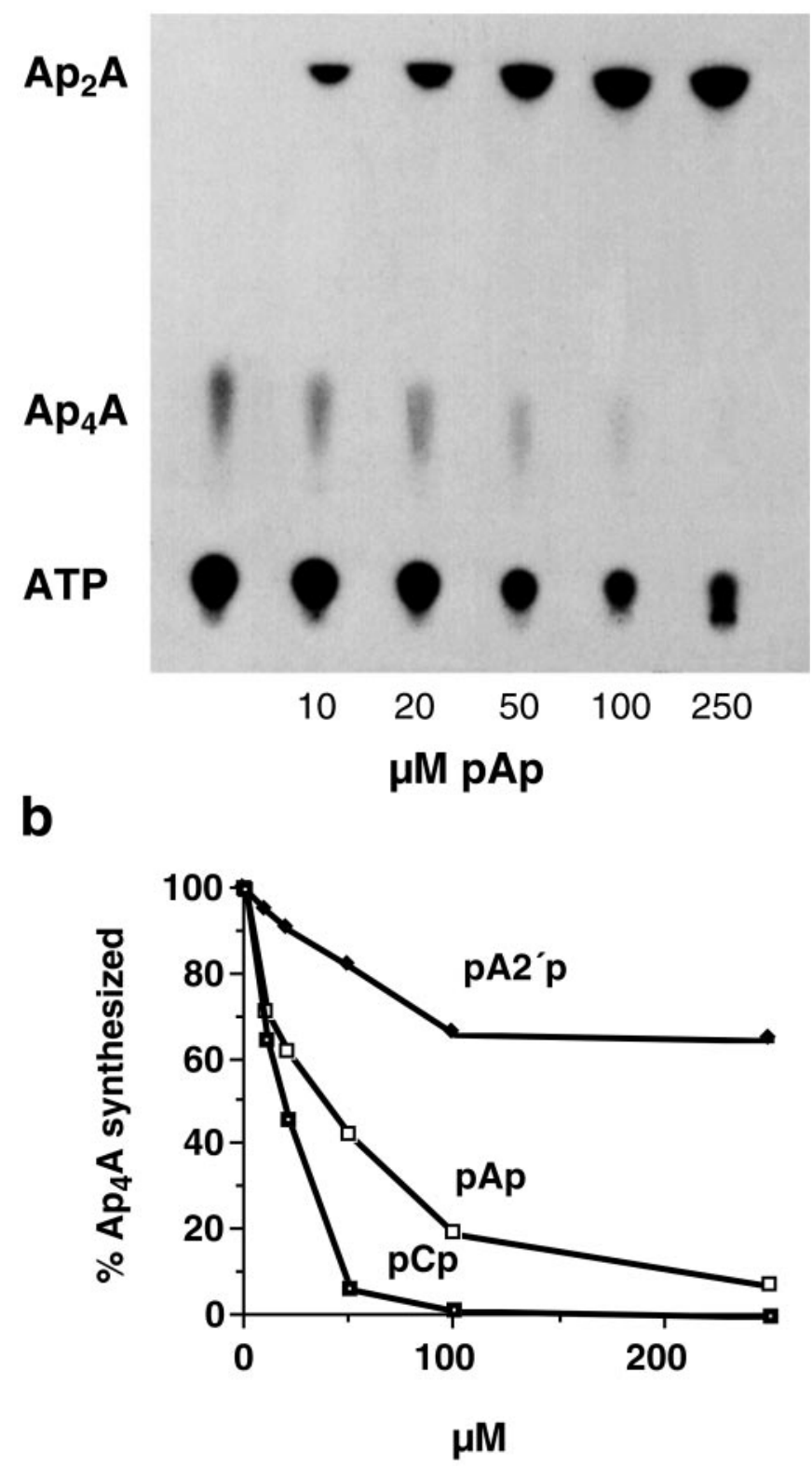

Fig. 7. Inhibition of the synthesis of $\mathbf{A p}_{4} \mathbf{A}$ by $\mathbf{T} 4 \mathrm{RNA}$ ligase donors. The reaction mixtures contained a fixed amount $(0.02 \mathrm{mM})$ of $\left[\alpha-{ }^{32} \mathrm{P}\right] \mathrm{ATP}$, other components as indicated in Materials and methods, 2 U T4 RNA ligase and variable concentrations of $\mathrm{pAp}, \mathrm{pA} 2 \mathrm{p}$ or $\mathrm{pCp}$. After 60 min incubation, the reaction mixtures were treated with $1 \mu \mathrm{g}$ alkaline phosphatase for $1 \mathrm{~h}$ at $37{ }^{\circ} \mathrm{C}$, subjected to TLC and the radioactivity corresponding to $\mathrm{Ap}_{4} \mathrm{~A}$, and to $\mathrm{Ap}_{2} \mathrm{~A}$, or $\mathrm{Ap}_{2} \mathrm{C}$ quantified in an InstantImager. (a) Autoradiography of the TLC plate of the experiment performed with pAp as inhibitor; (b) relative inhibition of the synthesis of $\mathrm{Ap}_{4} \mathrm{~A}$ by $\mathrm{pAp}, \mathrm{pA} 2 \mathrm{p}$ or $\mathrm{pCp}$.

appreciable effect on the synthesis of $\mathrm{Ap}_{4} \mathrm{~A}$ analyzed in the same experimental conditions as above.

\section{Conclusions}

As shown in this paper, T4 RNA ligase catalyzes the transfer of AMP from the E-AMP complex to diverse compounds, generating the products indicated between parentheses: ATP $\left(A p_{4} A\right) ; \operatorname{NTP}\left(A p_{4} N\right), P_{3}$ or $P_{4}\left(p_{4} A\right.$ or $\left.p_{5} A\right) ; A D P\left(A p_{3} A\right)$. In our view these reactions can be interpreted as a reversion of the first step of reaction [3], i.e. ATP $+\mathrm{E} \leftrightarrow \mathrm{E}-\mathrm{AMP}+\mathrm{PP}_{\mathrm{i}}$, where diverse polyphosphate derivatives can replace $\mathrm{PP}_{\mathrm{i}}$. The above reaction is favoured when the generated $\mathrm{PPi}$ is removed by pyrophosphatase, and it does not require the presence of RNA donors or acceptors. According to reactions (3 and 4), RNA donors could be expected to be inhibitors of the reaction, as NTP and RNA compete for the same E-AMP complex. That was the case when the synthesis of $\mathrm{Ap}_{4} \mathrm{~A}$ was tested in the presence of the known RNA donors, $\mathrm{pCp}, \mathrm{pAp}$ and $\mathrm{pA} 2$ ' $\mathrm{p}$. Their degree of inhibition of that synthesis was similar to their effectiveness described as RNA donors. By the contrary, an RNA acceptor, as dephosphorylated poly(A), does not compete with NTP for the E-AMP complex (compare Eqns 3 and 5) and would be expected not to be inhibitory of the synthesis of dinucleoside polyphosphates. The above opens perspectives referring to the potential use of (tri)polyphosphate derivatives as inhibitors of T4 RNA ligase.

\section{ACKNOWLEDGEMENTS}

We thank Isabel de Diego and Teresa Garcia for very able technical assistance. This investigation was supported by grants from the Dirección General de Investigación Cientîfica y Técnica (PM95/13) and Comunidad de Madrid (08.9/0004/1998)

\section{REFERENCES}

1. McLennan, A.G. (1992) Ap ${ }_{4}$ A And Other Dinucleoside Polyphosphates. CRC Press, Boca Raton, Florida, USA.

2. Kisselev, L.L., Justesen, J., Wolfson, A.D. \& Frolova, L.Y. (1998) Diadenosine oligophosphates $\left(\mathrm{Ap}_{\mathrm{n}} \mathrm{A}\right)$, a novel class of signaling molecules? FEBS Lett. 427, 157-163.

3. Baxi, M.D. \& Vishwanatha, J.K. (1995) Diadenosine polyphosphates: their biological and pharmacological significance. J. Pharmacol. Toxicol. Methods 33, 121-128.

4. Ohta, M., Inoue, H., Cotticelli, M.G., Kastury, K., Baffa, R., Palazzo, J., Siprashvili, Z., Mori, M., McCue, P., Druck, T., Croce, C.M. \& Huebner, K. (1996) The FHIT gene, spanning the chromosome 3p14.2 fragile site and renal carcinoma-associated t $(3 ; 8)$ breakpoint, is abnormal in digestive tract cancers. Cell 84, 587-597.

5. Barnes, L.D., Garrison, P.N., Siprashvili, Z., Guranowski, A., Robinson, A.K., Ingram, S.W., Croce, C.M., Ohta, M. \& Huebner, K. (1996) Fhit, a putative tumor suppressor in humans, is a dinucleoside $5^{\prime}, 5^{\prime \prime \prime}-\mathrm{P}^{1}, \mathrm{P}^{3}$ triphosphate hydrolase, Biochemistry 35, 11529-11535.

6. Sillero, M.A.G., Villalba, R., Moreno, A., Quintanilla, M., Lobatón, C.D. \& Sillero, A. (1977) Dinucleosidetriphosphatase from rat liver: purification and properties. Eur. J. Biochem. 76, 331-337.

7. Huang, Y., Garrison, P.N. \& Barnes, L.D. (1995) Cloning of the Schizosaccharomyces pombe gene encoding diadenosine $5^{\prime}, 5^{\prime \prime \prime}-\mathrm{P}^{1}, \mathrm{P}^{4}$ tetraphosphate $\left(\mathrm{Ap}_{4} \mathrm{~A}\right)$ asymmetrical hydrolase: sequence similarity with the histidine triad (HIT) protein family. Biochem. J. 312, 925-932.

8. Guranowski, A. \& Sillero, A. (1992) Enzymes cleaving dinucleoside polyphosphates. In $A p_{4} A$ and Other Dinucleoside Polyphosphates (McLennan, A.G., ed.), pp. 81-133. CRC Press, Boca Raton, Florida, USA.

9. Brenner, C., Garrison, P., Gilmour, J., Peisach, D., Ringe, D., Petsko, G.A. \& Lowenstein, J.M. (1997) Crystal structures of HINT demonstrate that histidine triad proteins are GalT-related nucleotidebinding proteins. Nat. Struct. Biol. 4, 231-238.

10. Lima, C.D., Klein, M.G. \& Hendrickson, W.A. (1997) Structure-based analysis of catalysis and substrate definition in the HIT protein family. Science 278, 286-290.

11. Guranowski, A.G., Günther Sillero, M.A. \& Sillero, A. (1990) Firefly luciferase synthesizes $\mathrm{P}^{1}, \mathrm{P}^{4}$-bis $\left(5^{\prime}\right.$-adenosyl) tetraphosphate $\left(\mathrm{Ap}_{4} \mathrm{~A}\right)$ and other dinucleoside polyphosphate. FEBS Lett. 271, 215-218.

12. Plateau, P. \& Blanquet, S. (1992) Synthesis of $\mathrm{Np}_{\mathrm{n}} \mathrm{N}(\mathrm{n}=3$ or 4$)$ in vitro and in vivo. In $A p_{4} A$ And Other Dinucleoside Polyphosphates 
(McLennan, A.G., ed.), pp. 63-79. CRC Press, Boca Raton, Florida, USA.

13. Guranowski, A., Günther Sillero, M.A. \& Sillero, A. (1994) Adenosine 5 -tetraphosphate and adenosine 5 '-pentaphosphate are synthesized by yeast acetyl coenzyme A synthetase. J. Bacteriol. 176, 2986-2990.

14. Fontes, R., Günther Sillero, M.A. \& Sillero, A. (1998) Acyl-CoA synthetase from Pseudomonas fragi catalyzes the synthesis of adenosine 5 '-polyphosphates and dinucleoside polyphosphates. J. Bacteriol. 180, $3152-3158$.

15. Ortiz, B., Sillero, A. \& Günther Sillero, M.A. (1993) Specific synthesis of adenosine (5') tetraphospho $\left(5^{\prime}\right)$ nucleoside and adenosine $\left(5^{\prime}\right)$ oligophospho $\left(5^{\prime}\right)$ adenosine $(\mathrm{n}>4)$ catalyzed by firefly luciferase. Eur. J. Biochem. 212, 263-270.

16. Madrid, O., Martín, D., Atencia, E.A., Sillero, A. \& Günther Sillero, M.A. (1998) T4 DNA ligase synthesizes dinucleoside polyphosphates. FEBS Lett. 433, 283-286.

17. Harnett, S.P., Lowe, G. \& Tansley, G. (1985) A stereochemical study of the mechanism of activation of donor oligonucleotides by RNA ligase from bacteriophage T4 infected Escherichia coli. Biochemistry 24, 7446-7449.

18. Cranston, J.W., Silber, R., Malathi, V.G. \& Hurwitz, J. (1974) Studies on ribonucleic acid ligase. Characterization of an adenosine triphosphateinorganic pyrophosphate exchange reaction and demonstration of an enzyme-adenylate complex with T4 bacteriophage-induced enzyme. J. Biol. Chem. 249, 7447-7456.

19. Uhlenbeck, O.C. \& Gumport, R.I. (1982). T4 RNA ligase. The Enzymes 15B, 31-58.

20. Brennan, C.A., Manthey, A.E. \& Gumport, R.I. (1983) Using T4 RNA ligase with DNA substrates. Methods Enzymol. 100, 38-52.

21. Romaniuk, P.J. \& Uhlenbeck, O.C. (1983) Joining of RNA molecules with RNA ligase. Methods Enzymol. 100, 52-59.

22. Tessier, D.C., Brouseau, R. \& Vernet, T. (1986) Ligation of singlestranded oligodeoxyribonucleotides by T4 RNA ligase. Anal. Biochem. 158, 171-178.

23. Marques, A.F.P., Teixeira, N., Gambaretto, C., Sillero, A. \& Günther Sillero, M.A. (1998) IMP-GMP 5'-nucleotidase from rat brain: activation by polyphosphates. J. Neurochem. 180, 3152-3158.

24. Webb, M.R. \& Trentham, D.R. (1980) Analysis of chiral inorganic $\left[{ }^{16} \mathrm{O},{ }^{17} \mathrm{O},{ }^{18} \mathrm{O}\right]$ thiophosphate and the stereochemistry of the 3-phosphoglycerate kinase reaction. J. Biol. Chem. 255, 1775-1779.

25. Kornberg, A. \& Baker, T.A. (1992) DNA Replication. Freeman, New York. 